\title{
RETAIL SPACE FOR RENT! MACROECONOMIC DETERMINANTS OF SHOPPING COMPLEX OCCUPANCY RATE
}

\author{
Shan-Shan Goh \\ University of Malaya \\ Tuck-Cheong Tang* \\ University of Malaya \\ Alex Hou-Hong Ng \\ INTI International University
}

\begin{abstract}
This study proposes an ad hoc equation which is applied to estimate the impacts of macroeconomic variables on occupancy rate of shopping complex. The candidate macroeconomic determinants are interest rate, inflation rate, share price and Gross Domestic Product (GDP), while a supply-side variable, total space is included. Using quarterly data between 1992 and 2015 from a small open economy - Malaysia, this study finds that interest rate, and GDP both have a positive impact on shopping complex's occupancy rate, and total space of shopping complex shows a negative sign. The non-causality tests offer that inflation rate indirectly causes the occupancy rate of shopping complex. This study highlights some relevant policy implications.
\end{abstract}

Keywords: Macroeconomics; Malaysia; Occupancy rate; Shopping complex; Time series

Received: 31 January 2019

Accepted: 30 December 2019

\section{INTRODUCTION}

This study explores the impact of a set of macroeconomic variables, namely real interest rate, real share price, price level, and real Gross Domestic Product (GDP) as well as total space on the occupancy of shopping complexes (shop space) for a small open economy, Malaysia. There are many shopping complexes/malls established in Malaysia i.e. that about 255 malls in Klang Valley, and 14 more shopping malls are planning to be opened for 2018 years (Achariam, 2017). As broadcasted by Cable News Network (CNN), the existing three malls in Malaysia had been ranked as top 10 largest shopping malls around the world i.e. One Utama Shopping Centre, Mid Valley Megamall, and Sunway Pyramid (Gerald, 2013). Nevertheless, the mall glut situation becomes worst in 2018 as shopping mall occupancy space is expected to reach 60 million s.f. which can cause oversupply and it will bring more pressure to the owners as well, because its demand cannot match with the excess supply of retail space (Augustin, 2017). For example, Ampang Park Shopping Centre, the first shopping mall in Kuala Lumpur had been 'forced' to close down because

\footnotetext{
* Corresponding author: Tuck Cheong Tang, Department of Economics, Faculty of Economics and Administration, University of Malaya, 50603 Kuala Lumpur, Malaysia. Email: tangtuckcheong@um.edu.my
} 
of the Klang Valley Mass Rapid Transit project. An article entitled "Time to say goodbye to the country's first shopping mall" documents that this shopping mall has no more potential to compete with other new shopping malls and keep struggle with the market needs (The Malay Online Mail, 2017). Another example is SS2 (Sungei Way-Subang 2) mall.

Figure 1 shows an upward trend of total space (in s.m, the bars). The occupancy rates ( $\%$, the line) are variable between 1992 and 2000 with 52\% (in 1992), and 86\% (in 1993), but it remains 'stable' between $2001(77 \%)$ and $2015(82 \%)$ with a sharp increase the total space supplied i.e. from 6,136 in 2001 to 13,828 (in thousand s.m.) in 2015. It clearly witnesses an oversupply of shopping complexes as occupancy rate is found to be below total space supplied, for example, there is about $15 \%$ not occupied in 2015. The occupancy rate of existing shopping complexes dropped from 1997 to 1998 during the 2017 Asian financial crisis for the years that the demand of shopping mall's space is deeply affected as entrepreneurs have tighten resources.

Also, occupancy rate of shopping complexes slowdown gradually between 2010 (81\%) and 2012 (79\%). Malaysia is reaching a mall glut situation especially in Klang Valley in 2017, and it expects to grow rapidly in the next three years (Izzat, 2017). The mall glut situation will become worst in 2018 and it reported that shopping mall occupancy space expected to reach 60 million sf. An oversupply of shopping malls will bring more pressure to the owners because of the demand cannot meet up with the excess supply of retail space (Augustin, 2017). In addition, a local [Malaysian] newspaper, The Star reports that oversupply of shopping malls seems is an issue that needs serious attention because some of the new malls postponing their opening - comparing to a few years back, retail occupancy rates in Klang Valley have decreased from 90\% (and above) to 78\%. This situation is reflected by too many "poor" malls that build at the non-strategic location, and other factors (Puspadevi, 2016). With so many malls established around Klang Valley, the density of malls increase gradually, and it becomes the case that some of the shopping malls are locating too near to others. For example, the distance between Tropicana City Mall, and Atria Mall only about $2.8 \mathrm{~km}$, and there is only $4.5 \mathrm{~km}$ distance from Tropicana City Mall to Starling Mall.

In contrary, other view expresses that there is never an oversupply of shopping malls in Malaysia as the quarterly data from National Property Information Centre (NAPIC), between 2013Q4 and 2017Q1, 99 new shopping malls are added to a total of 972 shopping malls. Ricard Chan, advisor for Persatuan Pengurusan Kompleks Malaysia, mentioned that actually developers should understand what the market needs and what the consumers' future preferences (Lin, 2017). However, according to Ling, Almeida, Muhamad, and Lim (2017), there is a phenomenon of oversupply of shopping malls in certain areas in Malaysia, namely Klang Valley, Penang, and Johor even though the total occupancy rate of shopping malls in Malaysia show a sharply increasing trend over the years. Among these states, Penang had the highest occupancy rates in Malaysia, and it is followed by Klang Valley, and Johor - another 140 more shopping malls are opening soon in these three areas. They add that the oversupply of shopping complexes and office space in Malaysia, especially the major states will be exacerbated by incoming supply, which is potentially more severe than of the Asian financial crisis. They also highlight two major issues to be concerned. The first is the large incoming supply of commercial properties, and the second is about the high vacancy rate and low rental rates in existing buildings. As policy option outlined, managing new incoming supply is proposed for the first issue, while repurposing vacant 
commercial buildings, and increasing demand for existing space are recommended for the second issue.

Figure 1: Existing Shopping Complexes Total (in s.m) and Occupied Space (\%) in Malaysia, 1992-2015

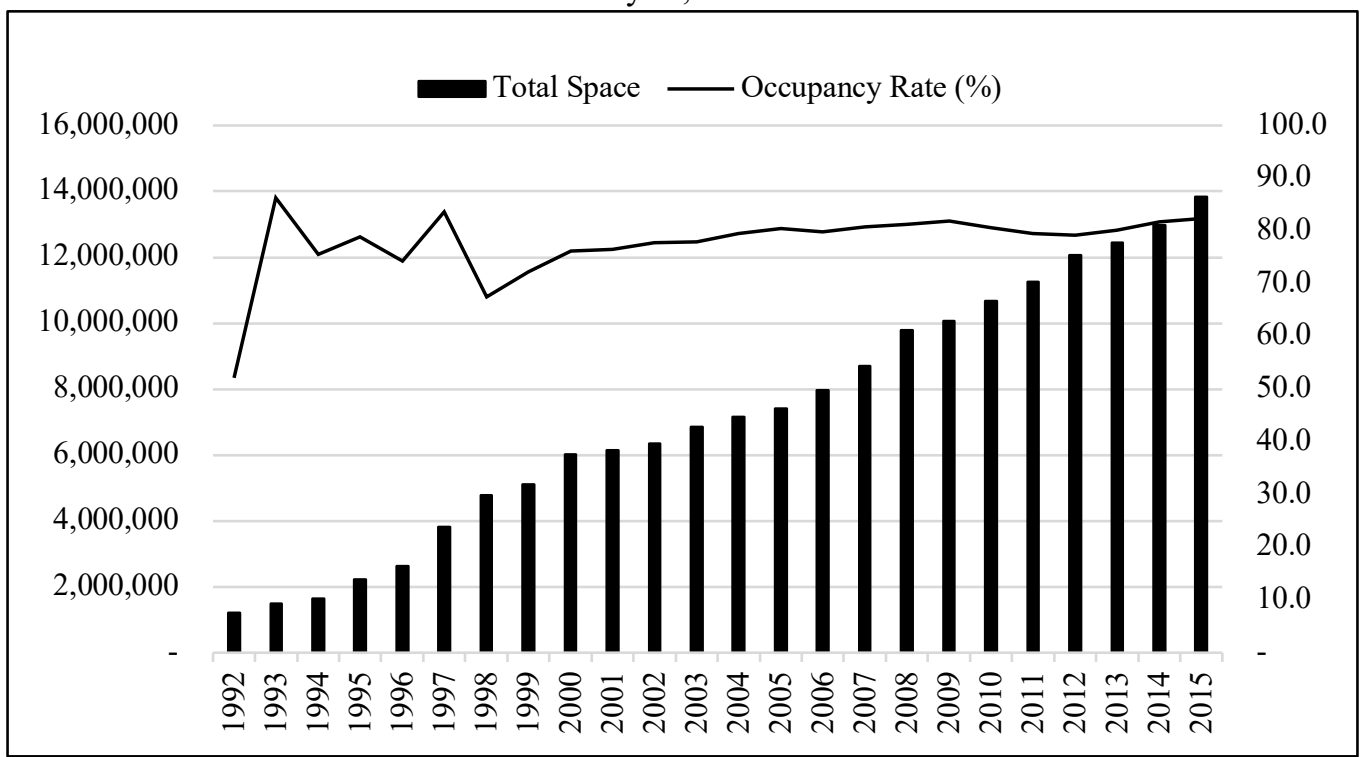

Source: National Property Information Centre

A few of research looks at the building characteristics or geographical factors in explaining the building occupancy rate. An early work by Sirmans, Sirmans, and Benjamin (1994) find a positive effect of landlord-supplied rental concessions on both on apartment rent and occupancy rates, but a negative relationship is observed between rent and occupancy rates. Chiuri and Jappelli's (2003) study shows that an increase in the down payment ratio, reduce equilibrium distribution of home owner occupancy rates at young age. The proportion of occupancy rate for a home ownership is relatively low for those countries which are relatively high down payment ratios. In Singapore, the retail landscape changed because of economic growth, and social change (Yap, 1996) - in the past few years, retail markets in Singapore had faced difficult problems such as oversupply of retail space. Besides, those less competitive shopping malls which struggle with the market needs are considering to convert them to more sought-after office space rather than closed down due to unable to adapt the market. The Singapore Competition Commission (2008), in a market study finds that occupancy rates of private shop space in Singapore are considerably high which about $90 \%$. New malls with strategic location attract more retailers to operate their business i.e. located in residential estates and MRT stations. On the other hand, a report from the Hagerstown's Planning and Code Administration Department (2013) highlights that retail shopping centre occupied $88.4 \%(2,324,815 \mathrm{sq} \mathrm{ft})$ within Hagerstown, and the four essential factors affecting the shopping centers occupancy rate are i) recently constructed (within 10 years), ii) management issues (maintainance of building is poor and lack of parking facilities), iii) site issues (location of building is not strategic), and iv) optimally sited (located on major arterials near major 
intersections). By comparing the retail space occupied (sq ft) for between 2012 and 2013, the management issues has the highest implication than of recently constructed, site issues, and optimally sited. Duvenhage and Kruger (2017) note that retail property management teams neglect the influence of occupancy costs and the resultant profitability of different retail formats when assessing their decision to expand.

An article entitled "Kota Kinabalu Hit by Oversupply in Retail Space" published in 2017 informs that shopping malls in Sabah, facing risk of glut because of the toughness to gain full occupancy rate following by high prices of the property, and strictly loan application process imposed by bankers (Yusa, 2017). Kok (2018) has considered a few of selected shopping malls in Kuala Lumpur and Petaling Jaya areas in his study in order to examine the possible factors those influencing their rental and occupancy rate. The proposed factors are shopping mall's age, it's design, good location and accessibility, high population, high visibility and busy traffic area, current market economy condition, shopping mall's tenant mix, and consumer attributes. He finds that good location and accessibility, high population, high visibility and busy traffic area, are the most crucial factors. Tokosh's (2018) study finds that population and income are two important variables to have their impact on the mall occupancy and sales. The prototypical characteristics of "dead" malls are smaller in size, less population, and lower income market areas. Also, there are varying effects of renovation dates, competition, and market age. Gamon (2018) looks at the potential factors underlying the decision to rent space for at a Shopping Center at Nakhon Ratchasima Province in Thailand. The four [critical] factors are, physical shop space, amount of money paid for monthly rent by shop tenants, marketing activities conducted by shopping centers to attract both tenants and customers, and all tangible materials used for a particular business. More recently, Kiriri (2019) has identified and validated five key determinants of shopping mall attractiveness in Kenya, namely design and aesthetics, service options, convenience and safety, service employees, and utilitarian value. The convenience, and safety are the most important determinants.

This brief review illustrates that the available works contribute to the occupancy rate of shop space from the microeconomic perspective, but the macroeconomic factors are eventually ignored, especially for the shopping complexes in a small open economy, Malaysia. This study fills the gap by adding a better understanding that higher expected return (proxied by real interest rate) and economic performance (GDP) will improve the Malaysian occupancy rate of shopping complexes. But total space of shopping complex reveals unfavourable outcome (i.e. oversupply).

The rest of this study is organised by i) Model, data and methods; ii) Empirical results; iii) Discussion; iv) Conclusion; and v) Limitations of the study.

\section{MODEL, DATA AND METHODS}

Of the literature search, study on the occupancy behaviour of shop space with macroeconomic determinants with quantitative methods with proper analytical framework(s) is relatively vacuum. The available relevant studies (as documented in the Introduction section) are rather descriptive (qualitative) by looking at the relationships between the malls characteristics (other non-economic 
factors) and their occupancy. For examples, Yap (1996) reviews the retail markets in Singapore which faced difficult problems such as oversupply of retail space, while an online news written by Yusa (as footnote 9) is about the shopping malls in Sabah, and linking their discouraging occupancy rate to high prices of the property, and loan application process.

This study explores and proposes an ad hoc demand-side equation of the occupancy rate of shop space mall behaviour with four fundamental macroeconomic variables, namely interest rate, share price, price level, and GDP. And, it's functional form at time period $t$ in real term can be written as equation (1).

$$
\mathrm{RO}_{\mathrm{t}}=f\left(\mathrm{r}_{t}^{(+)}, \mathrm{SP}_{\mathrm{t}}{ }^{(+)}, \mathrm{Y}_{\mathrm{t}}^{(+)}, \mathrm{P}_{\mathrm{t}}{ }^{(-)}\right)
$$

where RO is occupancy rate of existing shopping complexes; $r$ is real interest rate; $\mathrm{SP}$ is real share price; $\mathrm{P}$ is price level; and $\mathrm{Y}$ is real GDP. These variables have an expected positive sign as superscripted, except for the price level, $\mathrm{P}$.

Of the ad hoc equation (1), the associations between the candidate macroeconomic variables and occupancy rate of shopping complexes are preliminary explained by conventional macroeconomic understandings and microeconomic fundamentals, in particular Hicks-Hansen model/IS-LM model, and profit maximization rule of a competitive market. It is assumed real interest rate (r) reflects real returns of investment in retail businesses, in which higher the rate may encourage entrepreneurs to penetrate their business in shopping complexes (i.e. higher occupancy rate). Also, a positive relationship is expected between occupancy rate, and share price (SP) that accumulated wealth of entrepreneurs (investors) is assumed by higher share price, and it allows them to penetrate (and retain) their business in shopping complexes. For the real GDP (Y), it captures a country's prosperity that an increase in GDP rises the demand for goods and services including the demand for retails spaces, especially in shopping complexes. However, price level (P) is assumed to have a negative implication on occupancy rate of shopping complexes. This macroeconomic variable captures the cost of living (i.e. higher the prices for goods and services), which may decrease the households' aggregate demand. If the entrepreneurs fail to response it [aggregate demand decreases] with their expected profit, they must exist the market by closing down their outlets at the shopping complexes. The variables have been transformed into natural logarithm, $l n$ expect for RO, and $\mathrm{r}$ as they are measured in a ratio. Hence, an empirical equation for equation (1) can be re-written as:

$$
\mathrm{RO}_{\mathrm{t}}=\beta_{0}+\beta_{1} \mathrm{r}_{\mathrm{t}}+\beta_{2} \ln \mathrm{SP}_{\mathrm{t}}+\beta_{3} \ln \mathrm{Y}_{\mathrm{t}}-\beta_{4} \ln \mathrm{P}_{\mathrm{t}}+\varepsilon_{t}
$$

By the same token, this study also looks at a supply-side factor that is the total space of existing shop space (TS) because of data availability, as illustrated in equation (3).

$$
\mathrm{RO}_{\mathrm{t}}=\beta_{0}+\beta_{1} \ln \mathrm{TS}_{\mathrm{t}}+\varepsilon t
$$

However, its expected relationship with the occupancy rate of shop space remains unclear. if $\beta_{1}<$ 0 (i.e. a negative sign), more shop space available, may result a lower occupancy rate which indicates the case of 'oversupply', but a positive association holds $\left(\beta_{1}>0\right)$ if there is a 'shortage' i.e. too many entrepreneurs (investors) want to expand their business. It may be no relationship ( $\beta_{1}$ $=0$ ) given that the supply of shop space increases at the same proportion of the demand for the 
space that occupancy rate is constant. Equation (4) combines both equations (2) and (3) for both the demand-side and supply-side, respectively as ad hoc empirical equation to explore how these variables explain the occupancy rate of shop space.

$$
\mathrm{RO}_{\mathrm{t}}=\beta_{0}+\beta_{1} \mathrm{r}_{\mathrm{t}}+\beta_{2} \ln \mathrm{SP}_{\mathrm{t}}+\beta_{3} \ln \mathrm{Y}_{\mathrm{t}}-\beta_{4} \ln \mathrm{P}_{\mathrm{t}}+\beta_{5} \ln \mathrm{TS}_{\mathrm{t}}+\varepsilon t
$$

This study looks at a small open economy, Malaysia as a case study. Data for the occupancy rate (\%) of existing shopping complexes (RO), and total space (TS) (in s.m) are obtained from National Property Information Centre (http://napic.jpph.gov.my/). The data are available with only 23 annual observations from 1992 until 2015 which is ultimately insufficient in time series analysis with a rule of thumb of at least 30 observations to generate readable inference. To handle this concern, annual data, occupancy rate (RO) and total space (TS) have been then converted into quarterly observations by interpolating the data with Quadratic-match average method, which yield 96 observations. The raw data of interest rate (r), share price (SP), price level (P), and GDP (Y) are obtained from the International Financial Statistics (IFS), International Monetary Fund (IMF) covering quarterly observations between 1992q1-2015q4. These respective variables are then converted into their real term that real interest rate (in \%), $\mathrm{r}$ is averaged [nominal] lending rate minus inflation rate; real share price $(2010=100)$, SP is share price divided by consumer price index; and real GDP, Y is measured in RM million $(2010=100)$. The price level, $\mathrm{P}$ is measured by consumer price index, CPI $(2010=100)$.

Table 1: Summary Statistics

\begin{tabular}{ccccccc}
\hline \hline & $\mathbf{R O}_{\mathbf{t}}$ & $\mathbf{T S}_{\mathbf{t}}$ & $\mathbf{P}_{\mathbf{t}}$ & $\mathbf{S P}_{\mathbf{t}}$ & $\mathbf{Y}_{\mathbf{t}}$ & $\mathbf{r}_{\mathbf{t}}$ \\
\hline Mean & $77.8 \%$ & $5,885,487$ & 85.5 & 85.0 & 73.9 & $4.4 \%$ \\
Median & $79.5 \%$ & $7,032,129$ & 84.3 & 87.0 & 74.0 & $4.8 \%$ \\
Maximum & $89.3 \%$ & $14,217,725$ & 114.6 & 123.6 & 135.4 & $8.4 \%$ \\
Minimum & $29.5 \%$ & $1,082,734$ & 60.9 & 33.7 & 35.8 & $-2.4 \%$ \\
Std. Dev. & $7.4 \%$ & 2.0 & 1.2 & 1.3 & 1.4 & $2 \%$ \\
\hline Skewness & -3.834 & -0.877 & -0.153 & -0.541 & -0.141 & -0.38 \\
Kurtosis & 23.096 & 2.659 & 1.984 & 2.662 & 2.058 & 3.18 \\
Jarque-Bera & 1850.461 & 12.779 & 4.500 & 5.143 & 3.867 & 2.435 \\
$(p$-value) & $(0.000)$ & $(0.002)$ & $(0.105)$ & $(0.076)$ & $(0.145)$ & $(0.296)$ \\
\hline \hline
\end{tabular}

Note: The statistics are computed from the raw unit of measurement as described early that is without natural logarithm (ln) transformation.

The summary statistics of the variables are reported in Table 1 for descriptive inference. The average rate of occupancy for existing shopping complexes (RO) are almost $90 \%$ (as measured by median), but the worst situation occurs with only $30 \%$ (minimum) in 1992q1. It reflects a situation of 'oversupply' of existing shopping complexes in Malaysia since it is not fully occupied (i.e. $100 \%$ ). The total space of the Malaysian existing shopping complexes (TS) is about 7,032 (in thousand s.m.) on average, and have doubled their space (i.e. 14,217 thousand s.m.) during the peak period. On average, the price level (P) as measured by CPI is about 84.3 , while the real share price index (SP) is 87.0, and 74.0 for real GDP (in index). The real returns of investment (interest 
rate, $r$ ) is about $4.8 \%$. It is observed that a positive correlation between $\mathrm{RO}$ and the macroeconomic variables as low $\mathrm{P}, \mathrm{Y}$ and $\mathrm{r}$ as well as $\mathrm{SP}$ with a low RO as comparing their maximum and minimum values.

Table 2: Phillips and Perron (1988) (PP) Unit Root Tests

\begin{tabular}{clcl}
\hline \hline Variable: & \multicolumn{1}{c}{ Levels } & First Differenced & I(d) \\
\hline $\mathrm{RO}_{\mathrm{t}}$ & $-7.708^{* * *}[4](0.000)$ & - & $I(0)$ \\
$\ln \mathrm{TS}_{\mathrm{t}}$ & $-2.267[5](0.447)$ & $-4.444^{* * *}[5](0.001)$ & $I(1)$ \\
$\ln \mathrm{P}_{\mathrm{t}}$ & $-2.870[3](0.177)$ & $-8.487^{* * *}[6](0.000)$ & $I(1)$ \\
$\ln \mathrm{SP}_{\mathrm{t}}$ & $-2.506[4](0.325)$ & $-8.158^{* * *}[3](0.000)$ & $I(1)$ \\
$\ln \mathrm{Y}_{\mathrm{t}}$ & $-4.525^{* * *}[16](0.002)$ & - & $I(0)$ \\
$\mathrm{r}_{\mathrm{t}}$ & $-3.745^{* *}[0](0.024)$ & - & $I(0)$ \\
\hline \hline
\end{tabular}

Notes: The unit root equation is with constant and linear trend for data at levels, while only constant is included for the first-differenced data. A value in [.] is bandwidth (using Bartlett kernel), and in (.) is $p$-value, ${ }^{* * *},{ }^{* *}$, and ${ }^{*}$ indicate significant at the level of $1 \%, 5 \%$, and $10 \%$, respectively.

Table 2 is the Phillips-Perron (PP) unit-root tests (Phillips and Perron, 1988) ${ }^{1}$ which show that the stationarity (or degree of integration, $I(\mathrm{~d})$ ) of the underlying variables are mixed i.e. $I(0)$ and $I(1)$. It is to note that the dependent variable, occupancy rate $\left(\mathrm{RO}_{\mathrm{t}}\right)$ is stationary at levels. Similar finding is also observed for real GDP $\left(\ln \mathrm{Y}_{\mathrm{t}}\right)$, and real interest rate $\left(\mathrm{r}_{\mathrm{t}}\right)$. Other variables, total space $\left(\mathrm{TS}_{\mathrm{t}}\right)$, prices level $\left(\mathrm{P}_{\mathrm{t}}\right)$ and real share prices $\left(\mathrm{SP}_{\mathrm{t}}\right)$, are found to be non-stationary, or at $I(1)$ process i.e. rejection of the null hypothesis of a unit root after first differencing $\left(\Delta \ln \mathrm{TS}_{\mathrm{t}}, \Delta \ln \mathrm{P}_{\mathrm{t}}\right.$, and $\left.\Delta \ln \mathrm{SP}_{\mathrm{t}}\right)$. Because of stationary property of $\mathrm{RO}_{\mathrm{t}}$, dependent variable, no cointegration among the variables in equations (2)-(4) can be delivered. To avoid the so-called 'spurious' regression in OLS (Ordinary Least Squares) estimator with non-stationary variables, the first-differenced data are being used $\Delta \ln \mathrm{TS}_{\mathrm{t}}, \Delta \ln \mathrm{P}_{\mathrm{t}}$, and $\Delta \ln \mathrm{SP}_{\mathrm{t}}$. The equations (2)-(4) can be estimated by OLS estimator as equations (2')-(4'):

$$
\begin{aligned}
& \mathrm{RO}_{\mathrm{t}}=\beta_{0}+\beta_{1} \mathrm{r}_{\mathrm{t}}+\beta_{2} \Delta \ln \mathrm{SP}_{\mathrm{t}}+\beta_{3} \ln \mathrm{Y}_{\mathrm{t}}-\beta_{4} \Delta \ln \mathrm{P}_{\mathrm{t}}+u_{t} \\
& \mathrm{RO}_{\mathrm{t}}=\beta_{0}+\beta_{1} \Delta \ln \mathrm{TS}_{\mathrm{t}}+u_{t}{ }^{\prime} \\
& \mathrm{RO}_{\mathrm{t}}=\beta_{0}+\beta_{1} \mathrm{r}_{\mathrm{t}}+\beta_{2} \Delta \ln \mathrm{SP}_{\mathrm{t}}+\beta_{3} \ln \mathrm{Y}_{\mathrm{t}}+\beta_{4} \Delta \ln \mathrm{P}_{\mathrm{t}}-\beta_{5} \Delta \ln \mathrm{TS}_{\mathrm{t}}+u_{t},
\end{aligned}
$$

By and large, it is worth noting a widely applied cointegration test namely, Autoregressive Distributed Lag (ARDL) approach by Pesaran, Shin, and Smith (2001) in their abstract that "... The asymptotic distributions of these statistics are non-standard under the null hypothesis that there exists no level relationship, irrespective of whether the regressors are I(0) or I(1)." This study also re-estimates equations (2')-(4') by this [ARDL] procedure, and their results are tabulated in Appendix A. Their computed $F$-statistics of bounds testing approach support that the underlying variables are cointegrated (or a long-run relationship exits). However, this study has a reservation on this approach given that the dependent variable, $\mathrm{RO}_{\mathrm{t}}$ is stationary $($ or $I(0))$, in which such a cointegration relation is eventually from other relation(s), let say, the price equation of $\ln \mathrm{P}$

\footnotetext{
${ }^{1}$ It is an alternative (nonparametric) method of controlling for serial correlation when testing for a unit root by estimating the nonaugmented Dickey-Fuller test equation, and modifies the $t$-ratio of the $\alpha$ coefficient so that serial correlation does not affect the asymptotic distribution of the test statistic. The null hypothesis is the underlying time series has a unit root. The details of this method is available in Phillips and Perron (1988).
} 
$-\ln \mathrm{SP}-\ln \mathrm{Y}$, instead of RO equation that of interest in this study. If the ARDL procedure with $I(0)$ dependent variable is assumed such as this study, the estimated RO equation may be interpreted with bias, and may deliver infeasible implications. The ARDL estimates of equations (2')-(4') with alternative dependent variable for occupancy of shopping complexes, the total space occupied $(\ln \mathrm{TSO})$ are available upon request from the corresponding author. Generally speaking, their results are consistent with RO dependent variable of the respective equations. Also, $\ln$ TSO is stationary or $I(0)$ as suggested by the Phillips-Perron test.

More comprehensively, the analysis of this study has also been extended by employing [pairwise] Granger non-casualty tests (Granger, 1969) as Granger has postulated that "all the cause occurs before effect". In the case of two time series variables, let say $X$ and $Y$, " $X$ is said to Granger-cause $Y$ if $Y$ can be better predicted using the histories of both $X$ and $Y$ than it can by using the history of $Y$ alone" (Granger, 1969). Indeed, this method helps to identify the possible transmission channels for the shopping complexes' occupancy rate from a set of variables i.e. right-hand side of equation (4') in a VAR (Vector Autoregression) framework. ${ }^{2}$ In brief, a VAR model of $X$ and $Y$ can be expressed as the following linear OLS regressions: $Y_{t}=a_{0}+a_{1} Y_{t-1}+\ldots+a_{p} Y_{t-p}+b_{1} X_{t-1}+\ldots+$ $b_{p} X_{t-p}+v_{t}$, and $X_{t}=c_{0}+c_{1} X_{t-1}+\ldots+c_{p} X_{t-p}+d_{1} Y_{t-1}+\ldots+d_{p} Y_{t-p}+v_{t}{ }^{\prime}$ under the null hypothesis $\mathrm{H}_{0}$ : $b_{1}=b_{2}=\ldots=b_{p}=0$ (i.e. $X$ does not Granger-cause $Y$ ) against the alternative hypothesis $\mathrm{H}_{\mathrm{A}}: b_{1} \neq$ $b_{2} \neq \ldots \neq b_{p} \neq 0$ (i.e. $X$ does Granger-cause $Y$ ). Again, the non-stationary variables are differenced once, i.e. $\Delta \ln T S_{t}, \Delta \ln P_{t}$, and $\Delta \ln S P_{t}$ as VAR model requires all time series variables to be stationary in levels, or $I(0)$. If the null hypothesis $\mathrm{H}_{0}$ is rejected at a given conventional level of significance, let say $10 \%$, causality is said from $X$ to $Y$. Similarly, $\mathrm{H}_{0}: d_{1}=d_{2}=\ldots=d_{p}=0$, against $\mathrm{H}_{\mathrm{A}}: d_{1} \neq d_{2}$ $\neq \ldots \neq d_{p} \neq 0$ for the $X$ equation, and ' $Y$ does Granger-cause $X$ ' if the $\mathrm{H}_{0}$ is being rejected at $10 \%$ level, for instance. A lag length of 4, 8, and 12 have been considered for the non-causality tests that different variables may requires different time span in their transmission channels.

\section{EMPIRICAL RESULTS}

This section presents the empirical results. Table 3 reports the estimated coefficients of the equations (2'), (3') and (4') by ordinary least squares (OLS) estimator. Initial OLS estimates are carried out illustrate structural breaks as showed by the CUSUM tests - outside the $5 \%$ critical bands. Thus, without zero-one dummy variables dummy variable(s) is then added (i.e. one for the break date, zero otherwise) for re-estimation. The steps have repeated and adding new dummy variables (as break dates showed in CUSUM) until the estimated equation is stable i.e. CUSUM tests inside the $5 \%$ critical bands. ${ }^{3}$ For the equation (2') - the demand-side equation, it shows that real GDP $(\ln \mathrm{Y})$, and real interest rate $(r)$ are statistically significant at $5 \%$ level. Their estimated coefficients have a positive sign, i.e. 0.14 , and 0.92 for GDP and interest rate, respectively. It reflects that higher the Malaysian real GDP (or output) as well as real interest rate (i.e. capture the real return of investments) increase the occupancy rate of shopping malls in Malaysia. Other variables such as change in share price $(\Delta \ln \mathrm{SP})$, and inflation rate $(\Delta \ln \mathrm{P})$ are statistically

\footnotetext{
${ }^{2}$ The Granger non-causality testing method is not outlined here, but it can make a reference to Granger (1969).

${ }^{3}$ The results are not reported here but available upon request.
} 
insignificant even at $10 \%$ level, and they play no role in explaining the shopping complexes' occupancy rate in Malaysia.

Table 3: Ordinary Least Squares (OLS) Estimates

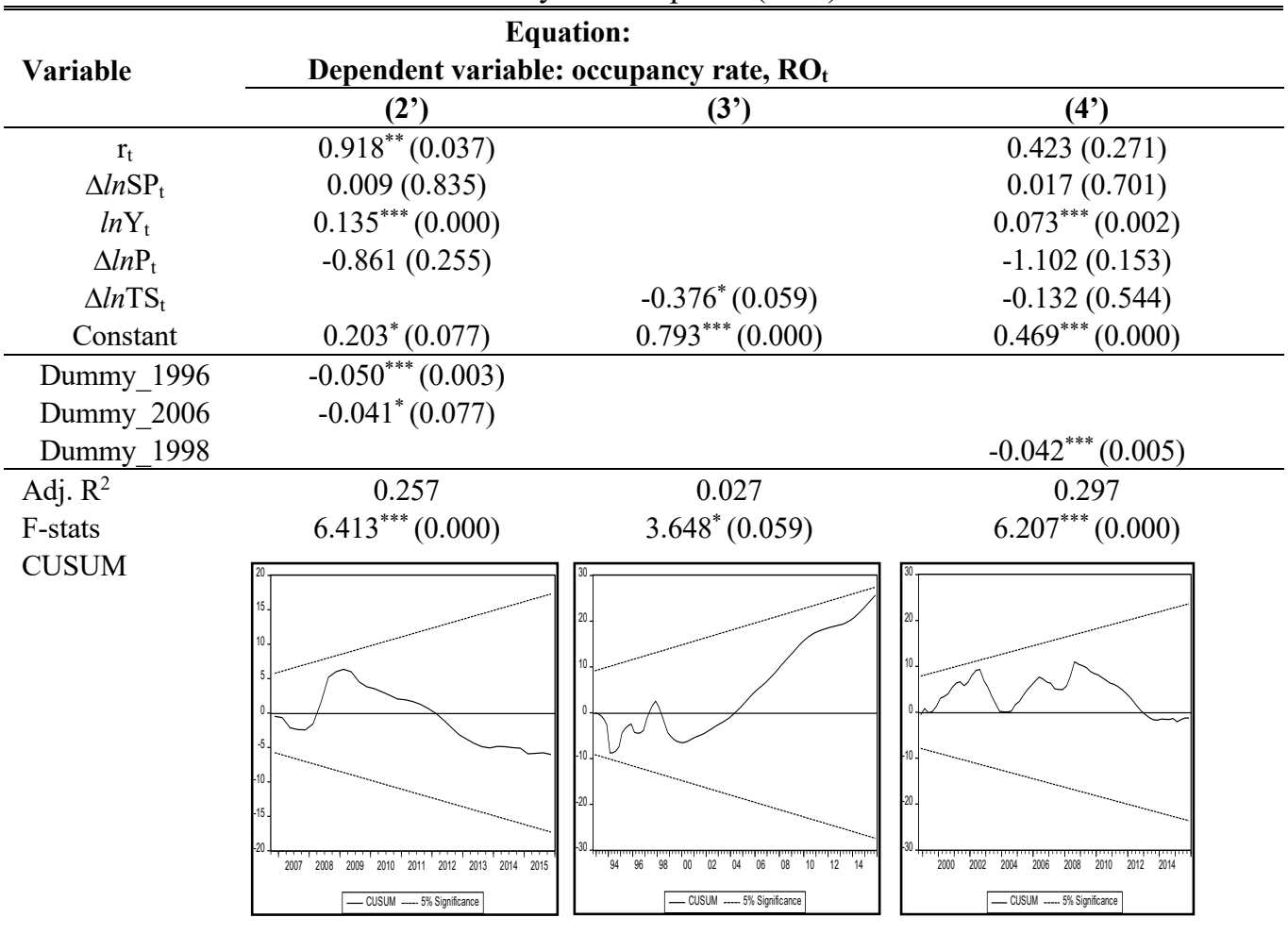

Notes: The figure in (.) is $p$-value. ${ }^{* * *},{ }^{* *}$, and ${ }^{*}$ indicate significant at the level of $1 \%, 5 \%$, and $10 \%$, respectively.

From the supply-side dimension, the estimated equation (3') suggests that change in total space supplied $(\Delta \ln \mathrm{TS})$ is statistically significant at $10 \%$ level, but in a negative sign, -0.38 implying that more shopping complexes (space) newly completed, lower its occupancy rate. It eventually indicates an 'oversupply' phenomena of shopping complexes in Malaysia. The equation (4') looks at both the demand-and supply-sides factors of the Malaysian occupancy rate of shopping complexes. It is interesting to inform that only real GDP $(\ln \mathrm{Y})$ is statistically significant at $10 \%$ level. Surprisingly, both the real interest rate (r) and growth in total space of shopping complexes $(\Delta \ln \mathrm{TS})$ become statistically insignificant. It shows that the country's real GDP rules out the influence of those two factors ( $r$ and $\Delta \ln \mathrm{TS})$.

In addition, the constant variable for all three estimated equations (2') - (4') is statistically significant at least $10 \%$ level. It suggests that the 'initial' or 'existing' occupancy rate of shopping complexes in Malaysia at any circumstance, there is a considerable percentage of existing shopping complexes space to be occupied. Lastly, the three zero-one dummy variables those capture the 
years 1996, 1998, and 2006, respectively are statistically significant at 10\% level (see, footnote 8 for their inclusion). They have a negative sign. The dummy variables are incorporated explained by the 2017 Asian financial crisis (pre-crisis 1996, and post-crisis1998), and 2006 Global financial recession of 2008-2009. During these crises, occupancy rate of shopping complexes has been undoubtedly affected as decreasing of investment, and there are no incentives for investors to run the particular business and reduce occupancy rate of shopping malls.

Table 4: Test Statistics of Granger Non-Causality Tests

\begin{tabular}{|c|c|c|c|}
\hline Lags: & 4 & 8 & 12 \\
\hline Null Hypothesis: & $F$-Statistic (p-value) & $F$-Statistic (p-value) & $F$-Statistic (p-value) \\
\hline $\mathrm{r}_{\mathrm{t}}=/=>\mathrm{RO}_{\mathrm{t}}$ & $5.166^{* * *}(0.001)$ & $1.884^{*}(0.076)$ & $1.673^{*}(0.097)$ \\
\hline $\mathrm{RO}_{\mathrm{t}}=/=>\mathrm{r}_{\mathrm{t}}$ & $1.883(0.121)$ & $0.475(0.870)$ & $0.326(0.982)$ \\
\hline$\Delta \ln \mathrm{SP}_{\mathrm{t}}=/=>\mathrm{RO}_{\mathrm{t}}$ & $1.391(0.244)$ & $2.905^{* * *}(0.007)$ & $2.340^{* *}(0.016)$ \\
\hline $\mathrm{RO}_{\mathrm{t}}=/=>\Delta \ln \mathrm{SP}_{\mathrm{t}}$ & $2.102^{*}(0.088)$ & $2.461^{* *}(0.021)$ & $3.975^{* * *}(0.000)$ \\
\hline $\ln \mathrm{Y}_{\mathrm{t}}=/=>\mathrm{RO}_{\mathrm{t}}$ & $2.626^{* *}(0.040)$ & $3.436^{* * *}(0.002)$ & $2.532^{* * *}(0.009)$ \\
\hline $\mathrm{RO}_{\mathrm{t}}=/=>\ln \mathrm{Y}_{\mathrm{t}}$ & $1.892(0.119)$ & $1.616(0.136)$ & $3.594^{* * *}(0.000)$ \\
\hline$\Delta \ln \mathrm{P}_{\mathrm{t}}=/=>\mathrm{RO}_{\mathrm{t}}$ & $0.076(0.989)$ & $0.216(0.987)$ & $0.395(0.960)$ \\
\hline $\mathrm{RO}_{\mathrm{t}}=/=>\Delta \ln \mathrm{P}_{\mathrm{t}}$ & $0.454(0.769)$ & $0.591(0.782)$ & $0.454(0.933)$ \\
\hline$\Delta \ln \mathrm{TS}_{\mathrm{t}}=/=>\mathrm{RO}_{\mathrm{t}}$ & $12.501^{* * *}(0.000)$ & $8.883^{* * *}(0.000)$ & $11.341^{* * *}(0.000)$ \\
\hline $\mathrm{RO}_{\mathrm{t}}=/=>\Delta \ln \mathrm{TS}_{\mathrm{t}}$ & $2.990^{*}(0.023)$ & $2.338^{* *}(0.028)$ & $3.862^{* * *}(0.000)$ \\
\hline$\Delta \ln \mathrm{SP}_{\mathrm{t}}=/=>\mathrm{r}_{\mathrm{t}}$ & $2.144^{*}(0.083)$ & $0.971(0.466)$ & $0.988(0.471)$ \\
\hline $\mathrm{r}_{\mathrm{t}}=/=>\Delta \ln \mathrm{SP}_{\mathrm{t}}$ & $0.993(0.416)$ & $1.445(0.193)$ & $1.573(0.125)$ \\
\hline $\ln \mathrm{Y}_{\mathrm{t}}=/=>\mathrm{r}_{\mathrm{t}}$ & $4.735^{* * *}(0.002)$ & $1.093(0.378)$ & $1.100(0.377)$ \\
\hline $\mathrm{r}_{\mathrm{t}}=/=>\ln \mathrm{Y}_{\mathrm{t}}$ & $1.843(0.128)$ & $2.267^{* *}(0.032)$ & $1.994^{* *}(0.041)$ \\
\hline$\Delta \ln \mathrm{P}_{\mathrm{t}}=/=>\mathrm{r}_{\mathrm{t}}$ & $13.395^{* * *}(0.000)$ & $4.715^{* * *}(0.000)$ & $2.342^{* *}(0.016)$ \\
\hline $\mathrm{r}_{\mathrm{t}}=/=>\Delta \ln \mathrm{P}_{\mathrm{t}}$ & $1.047(0.388)$ & $0.899(0.523)$ & $0.970(0.487)$ \\
\hline$\Delta \ln \mathrm{TS}_{\mathrm{t}}=/=>\mathrm{r}_{\mathrm{t}}$ & $1.734(0.150)$ & $0.791(0.612)$ & $1.053(0.416)$ \\
\hline $\mathrm{r}_{\mathrm{t}}=/=>\Delta \ln \mathrm{TS}_{\mathrm{t}}$ & $1.549(0.196)$ & $0.455(0.883)$ & $0.745(0.702)$ \\
\hline $\ln \mathrm{Y}_{\mathrm{t}}=/=>\Delta \ln \mathrm{SP}_{\mathrm{t}}$ & $0.641(0.635)$ & $1.036(0.418)$ & $1.718 *(0.086)$ \\
\hline$\Delta \ln \mathrm{SP}_{\mathrm{t}}=/=>\ln \mathrm{Y}_{\mathrm{t}}$ & $22.335^{* * *}(0.000)$ & $6.549^{* * *}(0.000)$ & $4.169^{* * *}(0.000)$ \\
\hline$\Delta \ln \mathrm{P}_{\mathrm{t}}=/=>\ln \mathrm{SP}_{\mathrm{t}}$ & $4.176^{* * *}(0.004)$ & $3.089^{* * *}(0.005)$ & $1.780^{*}(0.073)$ \\
\hline$\Delta \ln \mathrm{SP}_{\mathrm{t}}=/=>\Delta \ln \mathrm{P}_{\mathrm{t}}$ & $1.027(0.399)$ & $0.684(0.704)$ & $0.44(0.940)$ \\
\hline$\Delta \ln \mathrm{TS}_{\mathrm{t}}=/=>\Delta \ln \mathrm{SP}_{\mathrm{t}}$ & $2.178^{*}(0.079)$ & $3.075^{* * *}(0.005)$ & $2.411^{* *}(0.013)$ \\
\hline$\Delta \ln \mathrm{SP}_{\mathrm{t}}=/=>\Delta \ln \mathrm{TS}_{\mathrm{t}}$ & $0.734(0.571)$ & $3.852^{* * *}(0.000)$ & $1.571(0.126)$ \\
\hline$\Delta \ln \mathrm{P}_{\mathrm{t}}=/=>\ln \mathrm{Y}_{\mathrm{t}}$ & $2.697^{* *}(0.036)$ & $2.107^{* *}(0.046)$ & $1.56(0.130)$ \\
\hline $\ln \mathrm{Y}_{\mathrm{t}}=/=>\Delta \ln \mathrm{P}_{\mathrm{t}}$ & $0.628(0.644)$ & $0.315(0.958)$ & $0.36(0.972)$ \\
\hline$\Delta \ln \mathrm{TS}_{\mathrm{t}}=/=>\ln \mathrm{Y}_{\mathrm{t}}$ & $2.267^{*}(0.069)$ & $3.540^{* * *}(0.002)$ & $1.985^{* *}(0.042)$ \\
\hline $\ln \mathrm{Y}_{\mathrm{t}}=/=>\Delta \ln \mathrm{TS}_{\mathrm{t}}$ & $2.811^{* *}(0.031)$ & $7.331^{* * *}(0.000)$ & $2.760^{* * *}(0.005)$ \\
\hline$\Delta \ln \mathrm{TS}_{\mathrm{t}}=/=>\Delta \ln \mathrm{P}_{\mathrm{t}}$ & $1.33(0.266)$ & $1.113(0.365)$ & $0.612(0.823)$ \\
\hline$\Delta \ln \mathrm{P}_{\mathrm{t}}=/=>\Delta \ln \mathrm{TS}_{\mathrm{t}}$ & $0.698(0.595)$ & $0.534(0.827)$ & $0.579(0.850)$ \\
\hline
\end{tabular}

Note: ${ }^{* * *},{ }^{* *}$, and ${ }^{*}$ indicate significant at the level of $1 \%, 5 \%$, and $10 \%$, respectively.

As noted early, the analysis also considers the causality patterns among the variables, in which the possible transmission channels can be detected. The Granger non-causality (Granger, 1969) results 
(i.e. their tests statistics) for VAR(4), VAR(8), and VAR(12) are reported in Table 4. Perhaps, Figure 2 graphically illustrates their causalities for convenient. An interesting finding is observed that inflation rate $\left(\Delta \ln \mathrm{P}_{\mathrm{t}}\right)$ which is statistically insignificant as in the OLS estimates, has different implication in non-causality tests, in which it indirect causes the occupancy rate of existing shopping complexes in Malaysia. Their direction of causation runs from inflation rate to occupancy rate via the three transmission channels as follows:

- Inflation -> Real GDP -> Total space -> Real share price -> Occupancy rate

- Inflation $->$ Real interest rate $->$ Occupancy rate

- Inflation $->$ Real share price -> Occupancy rate

Of this finding, three instruments can be considered by the Government in formulating relevant policies for improving the Malaysian shopping complexes occupancy. Let say, fiscal policy (i.e. Keynesian view on government expenditure to stimulate growth), monetary policy via. interest rate targeting, and/or regulatory on capital markets to spur their development, are favourable in order to ratify the 'oversupply' concern occurs in existing shopping complexes in Malaysia.

Figure 2: Granger Non-Causality Results (Occupancy Rate)

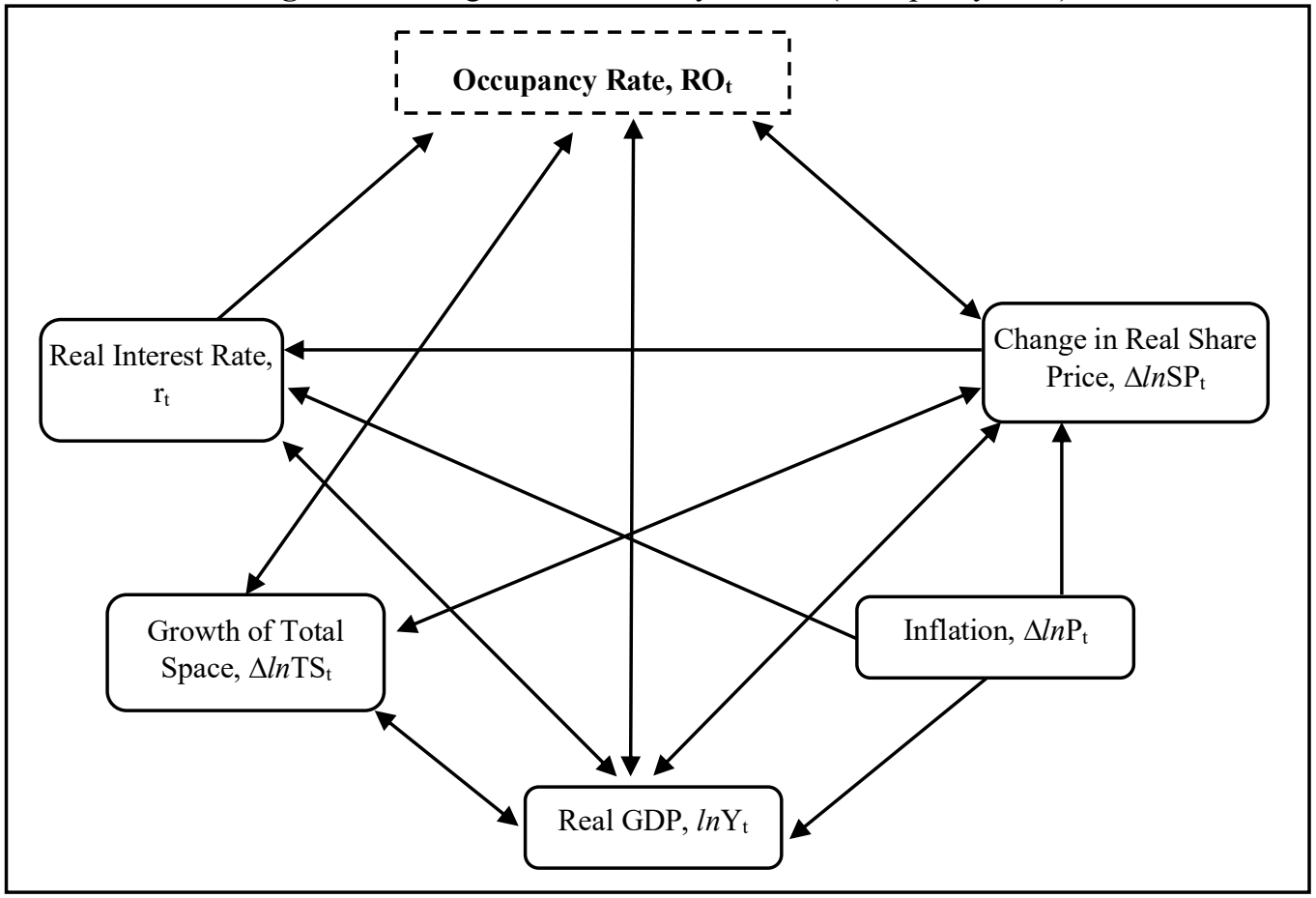

This section is also complemented by a robustness check, in which an alternative measure of total space occupied $(\ln \mathrm{TSO})$ has been used as dependent variable for all the three equations (2'), (3'), 
and (4). ${ }^{4}$ Overall, the findings are considerably robust. Consistent findings have been delivered for demand-side equation (2') that real income $(\ln \mathrm{Y})$, and real interest rate (r) are statistically significant. It is also the case that total space has a negative impact on the total space occupied, but the estimated equation is unstable i.e. the computed test statistics are outside the $5 \%$ critical bands as showed by the CUSUM plot. However, it is worth mentioning that equation (4') gives slightly different results, in which real interest rate $(\mathrm{r})$, real GDP $(\ln \mathrm{Y})$, total space $(\Delta \ln \mathrm{TS})$ are statistically significant at $1 \%$ level with total space occupied, while the real GDP is the only significant variable with occupancy rate as dependent variable. The three dummy variables those capture the year of 1996, 2013, and 2014 are statistically significant at $10 \%$ level. It shows a negative sign due to Asian financial crisis 2017-2018, and the slowing growth of economy in 2013 due to the financial slowdown in China (Zurairi, 2013). And, their causality patterns remain robust as in Figure 2.

\section{DISCUSSION}

This study is adopted the exploratory research design and focused on the shopping complexes' occupancy in the field of business economics. Most of the previous researches that have been reviewed in this study are qualitative method by design and relevant to the shopping malls or office spaces occupancy at large (Division, 2013; Nor Rima and Davies, 2011; Singapore Competition Commission, 2008; Sirmans et al., 1994; Yap, 1996; Yasmin and Nasir, 2010). However, none of the previous researches examined the relationships between aggregate occupancy rate of shopping complexes and macroeconomics variables with the application of time series econometrics tests. This section discusses a few concerns on the occupancy rate of the Malaysian shopping complexes based on the empirical findings from this study.

This study has found conclusive evidence that the Malaysian shopping malls are over-supplied. On the other hand, the demand of retail space is shrinking mainly due to most of the modern business start-up prefer to set up their retail businesses using e-commerce platform to avoid the high rental of retail space at the shopping complexes. Furthermore, most new breed of consumers (shoppers) in the digital era is heavily counting on the technologies and internet to do their shopping and buying online, unlike few decades ago where consumers almost bought everything from the local (physical) retail stores.

The consumer-packaged goods (CPG) transactions are increasingly happening on the internet as a substantial amount of the consumers are relying on the internet to shop (Roesler, 2018). A shift of the consumers' preference or taste in this online shopping 'mode' may explain the unfavoured occupancy rate of the Malaysian shopping complexes that currently observed (as in Figure 1). It is impossible to modify the consumers' preference or taste in the short-run from the perspective of behaviour economics but a life time, while online shopping tends to be the future of shopping. Therefore, it is worthwhile for the management of shopping malls as well as retailers to reconsider their business model in order to reduce the impact of decreasing (unfavoured) occupancy rate.

\footnotetext{
4 Their computed test statistics are not reported here, but available upon request from the corresponding author.
} 
From policy perspective, regulating both real interest rate and real GDP may have a positive implication on the Malaysian occupancy rate of shopping complexes in this context. For policy implication, Central Bank of Malaysia is recommended to have a reasonable real interest rate that reflects the real expected return of investment. As real expected return becomes higher, the more investors will tend to borrow external funds to run their business in the shopping malls, and therefore improve the occupancy rate of shopping malls. By offering a lower interest rate, it will lower down the cost of borrowing, and entrepreneurs had a cheaper cost of capital to run their businesses and it will increase the occupancy rate of shopping complexes as well. Meanwhile, fiscal policies can be adopted to stimulate economic growth viz. government spending, and tax system, are feasible to generate the Malaysian real GDP into a higher level, which also possible to improve the occupancy rate of existing shopping complexes.

By and large, shopping complexes can promote the so-called "tourism-led growth" strategy that has been aggressively adapted by many countries as one of their development strategies, in particular the developing economies like Malaysia. Indeed, shopping is the most favorite tourist activity, a study concludes that understanding the tourist shopping styles in accordance with their preferences and demographic characteristics is beneficial for shopping tourism and retail industry in Malaysia (Azila, Anis, Angayar, Hashim, \& Ngelambong, 2017). The Visit Malaysia 2020 that aims to realize the Malaysia Tourism Transformation Plan goals that by the year 2020, Malaysia will welcome a total of 36 million tourists and register RM168 billion in tourist receipts (Malaysia Tourism Promotion Board, 2019). Perhaps, no signal of oversupply of the shopping complexes in other developing countries like Thailand with the adoption of "tourism-led growth" strategy. The Thai shopping mall developers plan to invest more than 103 billion baht (or $\$ 2.83$ billion) over the next three years to expand and open more new stores as part of a strategic drive to promote Thailand as a regional shopping hub. In order to boost Thailand's competitiveness against Singapore and Hong Kong, the Thai government has been proposed to reduce import tax on luxury items and promote Thai brand products (Reuters, 2015).

\section{CONCLUSION}

It is a significant study in the field of business economics which adopted economic theory and econometric (quantitative) methods to further comprehend the business enterprises and the economic factors contributing (i.e. their relationships) to the occupancy rate of shopping malls in Malaysia. This study fills up the vacuum of the existing literature (mainly with descriptive analyses) by offering a fresh empirical finding on the impacts of macroeconomic variables on occupancy rate of the Malaysian shopping complexes. The underlying factors to be estimated are including real interest rate, real share price, price level, real GDP and total supply. The OLS estimates show real interest rate, and real GDP have positive impact on the occupancy rate (including, total space occupied) of shopping complexes in Malaysia. Changes in total supply have negative sign which strongly suggests an oversupply of shopping malls situation. On the other hand, Granger non-causality tests reveal the inflation rate is the core cause to the occupancy of existing shopping complexes) via. several channels of transmission. 


\section{LIMITATION}

Some drawbacks cannot be avoided from this study. They are outlined in this section as they are infeasible to be addressed in this study, but worth noting. Since this study is exploratory in the literature, the models proposed is being considered as ad hoc basis which looks at a few of macroeconomic variables those are believed to be potential in explaining the shopping malls' occupancy rate, in particular in Malaysia. Other potential macroeconomic variables may be omitted such as unemployment, globalization, financial development, institutional quality, and so on. It may result from the so-called "omitted variables bias" in the estimates. Perhaps, further study is needed by considering these omitted variables. Of course, theories from both the macroeconomics as well as micro foundations are important to support the variables to be included in the 'forthcoming' ad hoc empirical model. For example, to explore on how the occupancy rate of shopping malls is explained by the microeconomic theory (i.e. indirect utility function) that each consumer maximizes his/her utility subject to price and income. It is considerably relevant in explaining why the shopping complexes' occupancy rate is not $100 \%$ achieved - among the variables are amount of online shopping (transactions), tastes or preferences of consumers, demographic changes, urbanization, and so on with survey data such as households survey by either the government or statistical agencies (or both).

Secondly, this study only examines the Malaysian data, and ignore other countries. This study can be extended with inclusion of other countries' data for comparison purpose. It indeed will provide a better understanding on the relationships between shopping complexes' occupancy rates and its macroeconomic determinants outlined by this study. Some Asian countries, more precisely from ASEAN adopt the 'tourism-led growth' as their development strategy by promoting the country as a regional shopping hub. Hence, it suggests the relevance of this study to other countries such as Singapore, Indonesia. Thailand, Hong Kong (China), China, and other Asian countries. But, a crucial concern is their data are available via official statistical agencies of the respective countries.

Lastly, the methodology used in this study - OLS estimator for the underlying regression equations, and non-causality tests is conventionally applied by empirical researchers with one market assumption (i.e. generally, goods and services market) that does not capture the interlinkages among the markets in an economy - other markets such as financial market, labour market, and so on. To handle this concern, it is suggested that Computable General Equilibrium (CGE) modelling to be employed as the computed (simulations) results are more comprehensive and feasible for policymaking. But, it requires extremely comprehensive data (i.e. big data) both from microeconomics and macroeconomics overall markets which may not be publicly available, also the researchers are expected to be strongly equipped with CGE knowledge.

\section{REFERENCES}

Achariam, N. (2017, March 31). So many malls, so few shoppers. The Malaysian Insight. Retrieved from https://www.themalaysianinsight.com/s/960/ 
Augustin, R. (2017, February 28). Commercial properties glut to worsen in 2018, think tank warns. Free Malaysia Today News. Retrieved from: http://www.freemalaysiatoday.com/category/nation/2017/02/28/oversupply-ofcommercial-properties-to-worsen-in-2018-says-think-tank/

Azila, A., Anis, L. B., Angayar, K. R., Hashim, F. A., \& Ngelambong, A. (2017, August). Tourist Shopping Styles and Preferences in Kuala Lumpur, Malaysia. Conference paper for the Second International Conference on the Future of ASEAN. Retrieved from: https://www.researchgate.net/publication/319313705_Tourist_Shopping_Styles_and_Pr eferences

Chiuri, M. C., \& Jappelli, T. (2003). Financial market imperfections and home ownership: A comparative study. European Economic Review, 47(5), 857-875. doi:10.1016/S00142921(02)00273-8

Duvenhage, A., \& Kruger, A. (2017). Retail format selection: Occupancy cost and profitability. Journal of Economic and Financial Sciences, 10(2), 356-375.

Gamon, S. (2018). Factors underlying the decision to rent space at a shopping center at Nakhon Ratchasima province in Thailand: Using exploratory factor analysis. Catalyst, 18, 46-55.

Gerald, G. (2013, June 8). Malaysia has 3 of the top 10 largest malls in the world! Blogspot. Retrieved from http://bestfbkl.blogspot.my/2013/06/3-of-top-10-largest-malls-in-world2013.html

Granger, C. W. (1969). Investigating causal relations by econometric models and cross-spectral methods. Econometrica, 37(3), 424-438. doi:10.2307/1912791

Izzat, R. (2017, September 21). Mall occupancy stabilises as developers react to glut. The Malaysian Reserve. Retrieved from: https://themalaysianreserve.com/2017/09/21/malloccupancy-stabilises-developers-react-glut/

Kiriri, P. N. (2019). Determinants of shopping mall attractiveness: The case of shopping malls in Nairobi, Kenya. European Journal of Economics and Business Studies, 5(1), 258 -270.

Kok, J. Y. (2018). A Study on Rental \& Occupancy Rates of Shopping Malls in Kuala Lumpur and Petaling Jaya Areas. (Unpublished bachelor final year project), Tunku Abdul Rahman University College. Retrieved from http://eprints.tarc.edu.my/id/eprint/243

Lin, W. E. (2017, August 4). Never an oversupply of shopping malls. The Edge Financial Daily. Retrieved from http://www.theedgemarkets.com/article/never-oversupply-shoppingmalls.

Ling, C. S., Almeida, S., Muhamad, S., \& Lim, L. S. (2017). Box article 2: Imbalances in the property market. In Bank Negara Malaysia Quarterly Bulletin - Third Quarter 2017, 2632. Retrieved from https://www.bnm.gov.my/files/publication/qb/2017/Q3/p3 ba2.pdf

Malaysia Tourism Promotion Board. (2019). Visit Malaysia Year. Retrieved from https://www.tourism.gov.my/campaigns/view/visit-malaysia-2020

Nor Rima, M. A., \& Davies, H. (2011). Multi-owner low-cost housing management in Malaysia: Effects of ower-occupant characteristics and occupancy rates. International Journal of Housing Markets and Analsis, 13(1), 268-290. doi:10.1108/17538271111153031

Pesaran, M. H., Shin, Y., \& Smith, R. J. (2001). Bounds testing approaches to the analysis of level relationships. Journal of Applied Econometrics, 16(3), 289-326. doi:10.1002/jae.616

Phillips, P. C., \& Perron, P. (1988). Testing for a unit root in time series regression. Biometrika, 75(2), 335-346. doi:10.2307/2336182

Planning and Code Administration Department (2013). Retail Shopping Center Occupancy Study of the Greater Hagerstown Area 2013. Hagerstown. Retrieved from https://www.hagerstownmd.org/ 
Puspadevi, S. (2016, August 22). Proper retail mix’ ensures success of shopping malls. The Star. Retrieved from https:/www.thestar.com.my/business/business-news/2016/08/22/properretail-mix-ensures-success-of-shopping-malls/

Reuters. (2015, September 29). Thai malls to invest $\$ 2.8$ bln to promote regional shopping hub Retrieved from https://www.reuters.com/article/thailand-stores-expansion/thai-malls-toinvest-2-8-bln-to-promote-regional-shopping-hub-idUSL3N11Z20220150929

Roesler, P. (2018, April 16). New research reveals more consumers are shopping online for everyday items. Retrieved from https:/www.inc.com/peter-roesler/new-researchreveals-more-consumers-are-shopping-online-for-everyday-items.html

Singapore Competition Commission (2008). Market Study on Retail Mall Rental Space in Singapore. Competition Commission Singapore. Retrieved from https://www.cccs.gov.sg/resources/publications/market-studies

Sirmans, G. S., Sirmans, C., \& Benjamin, J. D. (1994). Apartment rent, concessions and occupancy rates. Journal of Real Estate Research, 9(3), 299-312.

The Malay Online Mail. (2017, December 24). Time to say goodbye to the country's first shopping mall. Retrieved from http://www.themalaymailonline.com/malaysia/article/time-to-saygoodbye-to-the-countrys-first-shopping-mall\#KxPRkIzbXUpjbLk7.97

Tokosh, J. (2018). You're dead to me, but should you be? Using a retail database to classify American malls by occupancy and sales and an extended analysis of dead and dying malls. International Review of Retail, Distribution and Consumer Research, 28(5), 490-515. doi: 10.1080/09593969.2018.1509801

Yap, C. (1996). Retailing and the retail space market in Singapore. Retail and Distribution Management, 24(8), 17-24. doi: 10.1108/09590559610127029

Yasmin, M. A., \& Md Nasir, D. (2010). Identification of impotant factors for office space Decision by tenants in Kuala Lumpur City Centre, Malaysia - experts' view. In the $16^{\text {th }}$ Pacific Rim Real Estate Society Annual Conference. Wellington, New Zealand, 24-27 January 2010. Retrieved from http://eprints.um.edu.my/11116/

Yusa. (2017, August 28). Kota Kinabalu hit by oversupply in retail space. Free Malaysia Today. Retrieved from http://www.freemalaysiatoday.com/category/nation/2017/08/28/kotakinabalu-hit-by-oversupply-in-retail-space/

Zurairi A. R. (2013, September 12). China's slowdown subduing Malaysia's growth. The Malay Mail Online. $\quad$ Retrieved from http://www.themalaymailonline.com/malaysia/article/chinas-slowdown-subduingmalaysias-growth 
APPENDIX A: Summary Results of Autoregressive Distributed Lag (ARDL) Approach

\section{Dependent variable: $\mathrm{RO}_{\mathrm{t}}$}

Equation:

(2')

(3')

(4')

\begin{tabular}{|c|c|c|c|}
\hline (1 & $\begin{array}{c}\text { ARDL }\left(\mathrm{RO}_{\mathrm{t}}, \mathrm{r}_{\mathrm{t}}, \ln \mathrm{SP}_{\mathrm{t}},\right. \\
\left.\ln \mathrm{Y}_{\mathrm{t}}, \ln \mathrm{P}_{\mathrm{t}}\right) \\
\mathrm{ARDL}(4,0,0,0,1)\end{array}$ & $\begin{array}{c}\operatorname{ARDL}\left(\mathrm{RO}_{\mathrm{t}}, \ln \mathrm{TS}_{\mathrm{t}}\right) \\
\operatorname{ARDL}(3,3)\end{array}$ & 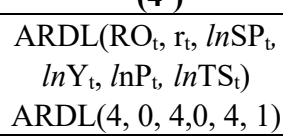 \\
\hline$F$-Statistic & $12.426^{* * *}$ & $13.782^{* * *}$ & $15.528^{* * *}$ \\
\hline \multirow{5}{*}{$\begin{array}{l}\text { Critical values } \\
\text { No. of regressor, } \\
\mathrm{k}=4 ; \\
\text { Finite Sample, } \\
\mathrm{n}=80\end{array}$} & $I(0) ; I(1)$ & $I(0) ; I(1)$ & $I(0) ; I(1)$ \\
\hline & ${ }^{*} 10 \% \quad 2.303 ; 3.220$ & $3.113 ; 3.61$ & $2.303 ; 3.154$ \\
\hline & ${ }^{* *} 5 \% \quad 2.688 ; 3.698$ & $3.740 ; 4.303$ & $2.550 ; 3.606$ \\
\hline & ${ }^{* * *} 1 \% \quad 3.602 ; 4.787$ & $5.157 ; 5.917$ & $3.351 ; 4.587$ \\
\hline & Coefficient ( $p$-value) & & \\
\hline $\ln \mathrm{TS}_{\mathrm{t}}$ & & $0.038^{* * *}(0.004)$ & $-0.0112(0.7911)$ \\
\hline$r_{t}$ & $-0.709^{* *}(0.013)$ & & $-2.312^{* * *}(0.000)$ \\
\hline $\ln \mathrm{SP}_{\mathrm{t}}$ & $0.017(0.278)$ & & $-0.030(0.421)$ \\
\hline $\ln \mathrm{Y}_{\mathrm{t}}$ & $0.270^{* * *}(0.001)$ & & $-0.242^{* *}(0.015)$ \\
\hline $\ln \mathrm{P}_{\mathrm{t}}$ & $-0.494^{* * *}(0.003)$ & & $-0.452^{* *}(0.040)$ \\
\hline Constant & $1.787^{* * *}(0.000)$ & & $2.191^{* * *}(0.000)$ \\
\hline $\begin{array}{l}\text { Error correction } \\
\text { term }\end{array}$ & $-0.496^{* * *}(0.000)$ & $-0.263^{* * *}(0.000)$ & $-0.420^{* * *}(0.000)$ \\
\hline $\begin{array}{l}\text { Breusch-Godfrey } \\
\text { LM test [2 lags] }\end{array}$ & $0.112(0.8945)$ & $3.163^{* *}(0.0474)$ & $1.692(0.191)$ \\
\hline $\begin{array}{l}\text { Ramsey Reset test } \\
\text { [2 lags] }\end{array}$ & $2.687^{*}(0.074)$ & $6.840(0.101)$ & $22.540^{* * *}(0.000)$ \\
\hline CUSUM 5\% & Stable & Unstable & Stable \\
\hline
\end{tabular}

Note: ${ }^{* * *},{ }^{* *}$, and ${ }^{*}$ indicate significant at the level of $1 \%, 5 \%$, and $10 \%$, respectively. 